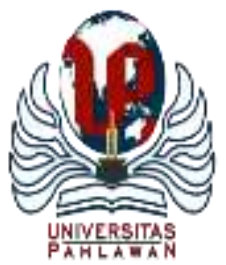

Edukatif : Jurnal Ilmu Pendidikan Volume 3 Nomor 6 Tahun 2021 Halm 4594 - 4604

EDUKATIF: JURNAL ILMU PENDIDIKAN

Research \& Learning in Education

https://edukatif.org/index.php/edukatif/index

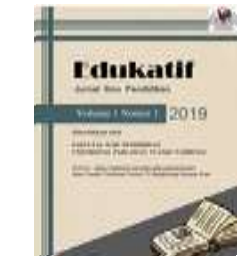

\title{
Pengembangan Bahan Ajar untuk Meningkatkan Pemahaman pada Mata Kuliah Akuntansi Menengah
}

\author{
Elisabeth Margareta \\ Pendidikan Ekonomi, Universitas HKBP Nommensen Pematangsiantar, Indonesia \\ E-mail : elisabeth.margareta@gmail.com
}

\begin{abstract}
Abstrak
Penelitian ini dilakukan karena mahasiswa angkatan 2019 program studi Pendidikan Ekonomi merasa bahan ajar dalam pembelajaran Akuntansi Menengah membosankan, media yang digunakan juga tidak menarik dan tidak interaktif. Tujuan penelitian ini adalah menguraikan prosedur pengembangan bahan ajar, menghasilkan bahan ajar yang layak, dan mendeskripsikan efektivitas pengembangan bahan ajar. Jenis penelitian adalah Research \& Development (R \& D) dengan mengadopsi model pengernbangan Allesi dan Trollip. Berdasarkan penelitian yang dilakukan diperoleh hasil bahwa uji alpha menunjukkan semua aspek bahan ajar yang dikembangkan sangat layak, uji beta 1 dan 2 juga menunjukkan keseluruhan aspek sangat layak. Untuk skor rata-rata pre-test dan post-test menunjukkan terjadi peningkatan dan dengan menggunakan rumus rata-rata gain yang dibandingkan ( $\mathrm{N}$-gain) diperoleh skor 0,72, yang berarti perbandingan skor rata-rata mahasiswa sebelum dengan sesudah menggunakan bahan ajar interaktif masuk dalam kategori tinggi. Dengan demikian dapat disimpulkan bahwa bahan ajar yang dikembangkan sangat layak digunakan pada mata kuliah Akuntansi Menengah dan sangat efektif dalam meningkatkan pemahaman materi Rekonsiliasi Bank.
\end{abstract}

Kata Kunci: Research \& Development $(R \& D)$, Alpha, Beta, Bahan Ajar, Akuntansi.

\begin{abstract}
This research was conducted because the 2019 students of the Economic Education study program felt that the teaching materials in Intermediate Accounting learning were boring, the media used were also unattractive and not interactive. The purpose of this research is to describe the procedure for developing teaching materials, to produce appropriate teaching materials, and to describe the effectiveness of developing teaching materials. The type of research is Research \& Development $(R \& D)$ by adopting the Allesi and Trollip development model. Based on the research conducted, it was found that the alpha test showed that all aspects of the teaching materials developed were very feasible, beta tests 1 and 2 also showed that all aspects were very feasible. For the average score of pre-test and post-test showed an increase and by using the formula for the average gain compared ( $N$-gain) obtained score 0.72, which means the comparison of the average score of students before and after using teaching materials interactive in the high category. Thus, it can be concluded that the teaching materials developed are very suitable for use in Intermediate Accounting courses and are very effective in improving understanding of Bank Reconciliation materials.
\end{abstract}

Keywords: Research \& Development $(R \& D)$, Alfa, Beta, Teaching Materials, Accounting

Copyright (c) 2021 Elisabeth Margareta

$\triangle$ Corresponding author

Email : elisabeth.margareta@gmail.com

DOI : https://doi.org/10.31004/edukatif.v3i6.1521

ISSN 2656-8063 (Media Cetak)

ISSN 2656-8071 (Media Online) 
4595 Pengembangan Bahan Ajar untuk Meningkatkan Pemahaman pada Mata Kuliah Akuntansi Menengah Elisabeth Margareta

DOI : https://doi.org/10.31004/edukatif.v3i6.1521

\section{PENDAHULUAN}

Undang-undang tentang Sistem Pendidikan Nasional No 20 Tahun 2003 menyatakan bahwa pembelajaran adalah proses interaksi peserta didik dengan pendidik dan sumber belajar pada suatu lingkungan belajar (Irawati \& Susetyo, 2017). Definisi di atas menunjukkan bahwa dalam pembelajaraan akan terjadi interaksi, yaitu interaksi pendidik dengan peserta didik. Selain interaksi pendidik dengan peserta didik, hal penting yang perlu diketahui bahwa ketika proses pembelajaran berlangsung perlu pemanfaatan media. Media pernbelajaran sangat penting digunakan untuk memaksimalkan kegiatan pernbelajaran, dengan demikian kegiatan belajar mengajar menjadi lebih hidup dan tentunya diharapkan tingkat pemahaman juga semakin meningkat (Siahaan et al., 2021). Banyak pendidik menggunakan beragam media bahkan mendesain media pembelajaran semenarik mungkin dengan harapan proses pembelajaran berhasil mencapai kompetensi dasar yang diharapkan. Kegiatan pembelajaran tidak terlepas dari komunikasi dan media pembelajaran merupakan alat atau sarana yang digunakan sebagai pendukung terlaksananya dengan baik proses komunikasi tersebut. Media sangat berperan bagi keberlangsungan pembelajaran. Itu berarti bahwa media memiliki posisi yang strategis sebagai bagian integral dari pembelajaran. Seperti yang dikatakan (Meidy et al., 2018), bahwa salah satu aspek untuk mencapai penguasaan terhadap materi diperlukan suatu media. Media pembelajaran dikatakan baik jika dapat memenuhi kebutuhan setiap peserta didik yang mengikuti proses pembelajaran. Media pembelajaran digunakan sebagai alat yang memfasilitasi berlangsungnya komunikasi dalam proses pembelajaran. Video, komputer, bahan cetak, bahkan televisi dapat juga menjadi media pembelajaran selama membawa pesan yang berhubungan dengan pembelajaran (Susanto \& Akmal, 2019).

Mahasiswa angkatan 2019 di program studi Pendidikan Ekonomi Universitas HKBP Nommensen Pematangsiantar dalam proses pembelajaran pada mata kuliah Akuntansi Menengah melaksanakan pembelajaran dengan metode ceramah, tanya jawab juga penugasan. Selain buku teks, modul dan bentuk tampilan teks lain, penulis juga menggunakan media visual dalam kegiatan pembelajaran untuk menyampaikan materi kepada mahasiswa berupa media visual projektor. Media visual projektor yang digunakan penulis adalah program komputer microsoft powerpoint. Bagi pengguna komputer, MicrosoftPower Point adalah aplikasi yang lazim digunakan dalam kegiatannya terutama pada saat presentasi. Microsoft Power Point adalah suatu software yang akan membantu dalam menyusun sebuahpresentasi yang efektif, professional, dan juga mudah (Warkintin \& Mulyadi, 2019).

Pada beberapa kesempatan terlihat metode ceramah membuat mahasiswa kurang aktif. Sama halnya dengan penelitian (Purnamasari et al., 2016), pembelajaran yang dilakukan masih menggunakan metode ceramah yang berpusat pada guru, akibatnya siswa cenderung bersifat pasif sehingga pengalaman belajar terbatas. Berdasarkan interview dengan mahasiswa diketahui bahwa bahan ajar yang digunakan membosankan bagi mereka karena hanya dilengkapi dengan teks. Media yang digunakan juga tidak membuat mahasiswa terlihat termotivasi dan tertarik dalam proses pembelajaran karena dianggap tidak menarik dan tidak interaktif. Dampaknya, mahasiswa kurang antusias terhadap materi yang disajikan sehingga pemahaman mahasiswa kurang, khususnya untuk topik Rekonsiliasi Bank pada materi Kas dan Setara Kas mata kuliah Akuntansi Menengah. Penyajian bahan ajar yang hanya menyajikan teks, selain menimbulkan kebosanan juga membuat mahasiswa kurang dapat berimajinasi dan cenderung cepat lupa sebab biasanya kita akan lebih ingat sesuatu yang kita lihat dan dengar daripada yang kita baca (MARGARETA, 2020).

Untuk mengevaluasi sejauh mana tingkat pemahaman mahasiswa akan konsep materi, penulis membuat kuis setelah melakukan pembelajaran Rekonsiliasi Bank pada materi Kas dan Setara Kas. Penulis berharap $70 \%$ mahasiswa memperoleh nilai " $\geq 81$ ", namun kenyataannya hanya $51 \%$ mahasiswa yang memperoleh nilai " $\geq 81$ ", $49 \%$ masih memperoleh nilai " $<81$ ". Karenanya, penulis merasa perlu mengembangkan bahan ajar yang telah digunakan agar lebih menarik dan interaktif sehingga setelah mahasiswa dan dosen menggunakannya dalam kegiatan pembelajaran, pemahaman mahasiswa akan topik Rekonsiliasi Bank pada 
4596 Pengembangan Bahan Ajar untuk Meningkatkan Pemahaman pada Mata Kuliah Akuntansi MenengahElisabeth Margareta

DOI : https://doi.org/10.31004/edukatif.v3i6.1521

materi Kas dan Setara kas akan meningkat sebab bahan ajar yang telah dikembangkan mampu meningkatkan antusiasme mahasiswa, kemampuan mahasiswa berimajinasi, dan kemampuan memecahkan masalah. Hal ini didukung oleh penelitian (Purmadi \& Surjono, 2016) yang menyatakan bahwa salah satu upaya yang dapat dilakukan untuk menciptakan pembelajaran yang terbaik untuk siswa adalah menggunakan sumber belajar yang bervariasi.

Bahan ajar memiliki beragam jenis yang terdiri dari bahan ajar cetak maupun non cetak. Bahan ajar cetak terdiri dari buku, handout, modul, brosur, dan lembar kerja siswa. Sedangkan bahan ajar non cetak meliputi bahan ajar dengar (audio) seperti kaset, radio, piringan hitam, dan compact disc audio (TANIA, 2017). Modul cetak yang telah digunakan dalam kegiatan pembelajaran merupakan bahan ajar yang akan dikembangkan oleh penulis menjadi modul elektronik. Modul cetak akan dikembangkan menjadi lebih interaktif untuk meningkatkan motivasi belajar mahasiswa, sebab seperti yang diungkapkan (Husada, 2020) bahwa proses pembelajaran tidak terlepas dari pentingnya peran bahan ajar. (Selvia et al., 2017) dalam penelitiannya mengatakan "adanya bahan ajar dapat membantu mengoptimalkan hasil belajar siswa, fungsinya sebagai alat atau sarana untuk mencapai standar kompetensi dan kompetensi dasar". Menurut pendapat (Widiana \& Rosy, 2021), menciptakan modul dalam bentuk yang lebih efisien dan menarik dapat menjadi salah satu cara agar peserta didik lebih tertarik dan berminat membaca sebab modul elektronik kerap dilengkapi dengan berbagai produk-produk interaktif seperti animasi, video, gambar dan audio. Selain itu, seperti yang diungkapkan (Seso et al., 2019), bahwa bahan ajar elektronik menjadi pilihan tepat bagi para siswa sebagai sumber belajar. Pada era digital seperti saat ini, para siswa mulai jarang untuk membuka apalagi membaca buku konvensional. Kemudahan akses informasi dengan teknologi informasi dan komunikasi menjadi penyebabnya. Penggunaan bahan ajar yang tepat akan sangat membantu tercapainya keefektifan dan penyampaian isi pembelajaran (Setyo \& Pribowo, 2017).

Modul elektronik tidak perlu dicetak. Dengan bantuan komputer, setelah teks digabungkan dengan gambar, audio, animasi, dan video dalam satu file, link file modul tersebut sudah dapat dibagikan kepada mahasiswa untuk dapat digunakan. Selaras dengan pendapat (Sulasteri et al., 2021), bahwa pembelajaran dengan bantuan komputer menjadi salah satu benda yang bisa membantu dosen dan mahasiswa. File modul dapat dibuka dan dibaca di PC atau laptop, namun jika tidak memilikinya mahasiswa bahkan bisa membuka dan membaca file di handphone sehingga memudahkan mahasiswa untuk bisa membacanya dimana saja dan kapan saja, apalagi saat ini tidak ada lagi mahasiswa yang tidak memiliki handphone.

Tujuan yang ingin dicapai dari penelitian ini adalah (1) menguraikan bagaimana prosedur pengembangan bahan ajar sehingga dapat meningkatkan pemahaman pada mata kuliah Akuntansi Menengah, (2) menghasilkan bahan ajar yang layak untuk meningkatkan pemahaman pada mata kuliah Akuntansi Menengah, (3) mendeskripsikan efektivitas pengembangan bahan ajar dalam meningkatkan pemahaman pada mata kuliah Akuntansi Menengah.

Akuntansi Menengah merupakan mata kuliah yang dikategorikan wajib di program studi Pendidikan Ekonomi. Salah satu materi yang dipelajari pada mata kuliah Akuntansi Menengah adalah Kas dan Setara Kas. Ada dua topik yang dibahas pada materi Kas dan Setara Kas yaitu Kas Kecil dan Rekonsiliasi Bank. Kas Kecil membahas tentang uang tunai yang disiapkan oleh perusahaan agar dapat digunakan membiayai pengeluaran-pengeluaran dengan jumlah relatif kecil yang sifatnya rutin, yang dianggap tidak akan ekonomis apabila dibayarkan perusahaan dengan cek atau giro, sedangkan Rekonsiliasi Bank membahas tentang upaya untuk mencari penyebab terjadinya selisih antara saldo kas menurut catatan akuntan perusahaan di buku besar perusahaan dengan jumlah saldo kas yang ada di bank menurut rekening koran bank. Untuk dapat menguasai topik Kas Kecil terlebih Rekonsiliasi Bank, mahasiswa harus mampu berpikir kritis, analitis dan logis. Menurut (Rudianto, 2012), rekonsiliasi bank adalah daftar yang berisi penyebab perbedaan selisih saldo kas menurut catatan perusahaan dan menurut catatan bank. Topik Rekonsiliasi Bank sering dianggap sulit oleh mahasiswa, untuk itu dibutuhkan bahan ajar yang mudah dipahami dan media pembelajaran yang didesain 
4597 Pengembangan Bahan Ajar untuk Meningkatkan Pemahaman pada Mata Kuliah Akuntansi Menengah Elisabeth Margareta

DOI : https://doi.org/10.31004/edukatif.v3i6.1521

dengan semenarik mungkin supaya peserta didik lebih termotivasi untuk belajar sehingga pemahaman akan materi meningkat dan capaian pembelajaran akan terwujud. Bahan ajar mencakup seluruh bahan maupun materi yang digunakan pendidik juga peserta didik selama kegiatan pembelajaran berlangsung, yang disusun secara sistematis agar capaian pembelajaran dapat terwujud. Bahan cetak merupakan salah satu bentuk bahan ajar. (Yaumi, 2018) menyatakan bahwa, "bahan cetak dalam pendidikan adalah semua bentuk cetakan seperti buku teks, modul, lembar kerja, artikel, jurnal, lembar lepas (handout), surat kabar, majalah dan berbagai bentuk cetakan lainnya yang digunkaan untuk kebutuhan pembelajaran." Semua bahan cetak ini akan memudahkan pendidik untuk menyampaikan informasi atau materi kepada para peserta didik sehingga lebih rnemudahkan pendidik selama proses pembelajaran. Modul merupakan salah satu bahan cetak yang sering dan penting digunakan oleh seorang pendidik. Sejalan dengan pernyataan (Sulistyowati \& Putri, 2018) dalam penelitiannya bahwa "bahan ajar memiliki posisi penting dalam pembelajaran, yakni sebagai representasi dari penjelasan guru. Salah satu jenis bahan ajar yang dapat kita gunakan adalah bahan ajar cetak berupa modul". Modul merupakan satuan kecil dari suatu pembelajaran yang dapat beroperasi sendiri (Yaumi, 2018), artinya dengan modul peserta didik bisa belajar mandiri. Modul pembelajaran disusun semenarik dan selengkap mungkin, penyusunannya dilakukan secara sistematis sehingga dapat berdiri sendiri tanpa harus tergantung dengan bahan ajar lain. Menurut (Anwar, 2010), modul pembelajaran merupakan bahan ajar yang disusun secara sistematis dan menarik dimana di dalam modul pembelajaran tersebut mencakup isi materi, metode dan evaluasi yang dapat digunakan secara mandiri (belajar sendiri) untuk dapat mencapai kompetensi yang diharapkan secara mandiri. (Prastowo, 2012) menyatakan bahwa modul pembelajaran sebagai salah satu bentuk bahan ajar memiliki empat fungsi, yaitu: (1) pengganti dari tenaga pengajar, (2) bahan ajar mandiri, (3) manjadi alat evaluasi, dan (4) menjadi bahan rujukan. Penelitian ini diharapkan bermanfaat untuk (1) menambah pengetahuan penulis tentang metode Penelitian dan Pengembangan (Research \& Development) serta meningkatkan kreativitas dalam pengembangan bahan ajar dan (2) memudahkan para peserta didik dalam hal pemahaman materi dan menambah pengetahuan tentang bahan ajar.

\section{METODE PENELITIAN}

Jenis penelitian ini adalah penelitian pengembangan, disebut juga Research \& Development (R \& D). Menurut (Setyosari, 2013), "penelitian yang diarahkan untuk menghasilkan produk, desain dan proses diidentifikasi sebagai suatu penelitian pengembangan.” Penelitian ini difokuskan pada efektivitas materi bahan ajar interaktif dalam meningkatkan pemahaman mahasiswa terhadap topik Rekonsiliasi Bank.

Tujuan penelitian ini adalah mengembangkan bahan ajar menjadi bahan ajar interaktif dengan harapan setelah menggunakan bahan ajar interaktif mahasiswa program studi Pendidikan Ekonomi dapat lebih termotivasi sehingga semangat belajar meningkat, dengan demikian diharapkan pemahaman terhadap mata kuliah Akuntansi Menengah pada materi Kas dan Setara Kas, khususunya topik Rekonsiliasi Bank semakin meningkat.

Menurut (Setyosari, 2013), "penelitian ini mengikuti suatu langkah-langkah secara siklus. Langkah penelitian atau proses pengembangan ini terdiri atas kajian tentang temuan penelitian produk yang akan dikembangkan, mengembangkan produk berdasarkan temuan-temuan tersebut, melakukan uji coba lapangan sesuai dengan latar dimana produk tersebut akan dipakai, dan melakukan revisi terhadap hasil uji lapangan." Model pengernbangan oleh Allesi dan Trollip adalah model penelitian yang digunakan oleh penulis, sama halnya dengan penelitian (Nurhairunnisah \& Sujarwo, 2018), dimana model pengembangan produk bahan ajar interaktif dalam penelitiannya diadaptasi dari Alessi dan Trollip. Model ini banyak digunakan karena terbilang sederhana sebab terdiri dari tiga tahapan saja, yaitu: planning, design, and development. Pada tahan planning yang dilakukan adalah: (1) menetapkan tujuan, menentukan materi kemudian menetapkan capaian pembelajaran, (2) mengidentifikasi karakteristik pengguna produk. Pada penelitian ini, pengguna produk 
4598 Pengembangan Bahan Ajar untuk Meningkatkan Pemahaman pada Mata Kuliah Akuntansi MenengahElisabeth Margareta

DOI : https://doi.org/10.31004/edukatif.v3i6.1521

bahan ajar interaktif adalah mahasiswa program studi Pendidikan Ekonomi angkatan 2019 Universitas HKBP Nommensen Pematangsiantar, (3) membuat dokumen perencanaan yang berisikan materi, yang menggabungkan teks, gambar, audio, animasi, dan video dalam satu file, (4) cakup semua material yang terlibat dalam pengembangan produk, (5) melakukan pembimbingan atau diskusi dengan pihak-pihak lain untuk menambah wawasan tentang pengembangan bahan ajar. Pada tahap design yang dilakukan adalah (1) membuat desain konten awal, misalnya ukuran teks, jenis huruf, gambar yang digunakan, audio yang dibutuhkan, animasi dan video yang mendukung, dimana semuanya disesuaikan dengan materi pembelajaran, (2) membuat peta konsep materi agar mudah dipahami, (3) membuat storyboards yang menjadi pedoman dalam mengembangkan bahan ajar interaktif.. Pada tahap development yang dilakukan adalah (1) menyesuaikan teks dengan Rencana Pembelajaran Semester (RPS) dan silabus, (2) menyiapkan gambar, animasi dan video yang dapat menjelaskan materi, (3) menggabungkan teks, gambar, audio, animasi, dan video menjadi satu file, (4) menambahkan bahan pendukung lain, jika ada, dan (5) mengcopy link file yang akan dibagikan kepada mahasiswa.

Untuk melakukan desain uji coba produk maka penulis melaksanakan beberapa tahapan, yaitu: (1) uji alpha, dimana ahli materi melakukan validasi instrumen yang telah disusun. Berdasarkan hasil yang diperoleh, jika masih ada yang harus direvisi maka revisi harus dilakukan tetapi jika sudah tidak ada lagi revisi berarti bisa dilakukan langkah selanjutnya yaitu uji beta, (2) uji beta, dilakukan untuk melihat bagaimana respon mahasiswa terhadap produk yang telah dikembangkan. Uji beta pertama diberikan kepada kelompok kecil mahasiswa, yaitu mahasiswa angkatan 2018 (grup A) yang sudah pernah mempelajari materi Kas dan Setara Kas topik Rekonsiliasi Bank. Uji beta kedua dilakukan kepada mahasiswa angkatan 2019 (grup A) yang sedang mengikuti pembelajaran Akuntansi Menengah materi Kas dan Setara Kas. Untuk menguji apakah produk yang dihasilkan efektif atau tidak maka selanjutnya dilakukan uji melalui soal pre-test dan post-test.

Mahasiswa angkatan 2019 merupakan subjek dalam penelitian ini dan ahli materi yang juga sebagai subjek coba berperan menguji kelayakan produk yang dikembangkan.

Teknik dan instrumen pengumpulan data pada penelitian ini dilakukan melalui penyebaran angket, pemberian tes, wawancara, dan observasi. (1) angket validasi diisi oleh ahli materi. Ahli materi adalah dosen yang mengajarkan mata kuliah Akuntansi Menengah. Setelah divalidasi, angket kemudian disebarkan kepada mahasiswa yang mengikuti pembelajaran mata kuliah Akuntansi Menengah, yaitu mahasiswa angkatan 2019 program studi Pendidikan Ekonomi, (2) tes yang diberikan berupa pre-test dan post-test. Hasil pre-test dan hasil post-test dibandingkan untuk melihat seberapa besar efektivitas penggunaan produk bahan ajar interaktif yang telah dikembangkan, (3) wawancara dilakukan sebelum memulai observasi untuk menganalisa apa yang menjadi kebutuhan mahasiswa, (4) observasi dilakukan untuk melihat bagaimana kondisi pembelajaran dan analisis kebutuhan mahasiswa guna mendukung pengembangan produk.

Untuk teknik analisis data, data kuantitatif diperoleh dari data angket dan data saran dari ahli materi sedangkan data kualitatif diperoleh dari respon mahasiswa setelah bahan ajar interaktif digunakan kemudian dianalisis. Selanjutnya, analisis data pre-test dan post-test dilakukan dengan memberikan pre-test dan posttest, kemudian dibandingkan hasilnya antara sebelum perlakuan (bahan ajar) dengan sesudah perlakuan (bahan ajar interaktif). Menurut (Hake, 1998), perbandingan hasil sebelum dengan sesudah perlakuan dihitung dengan rumus rata-rata gain yang dibandingkan ( $\mathrm{N}$-gain) berikut.

$$
g=\frac{\text { s post }- \text { s pre }}{\text { smaks }- \text { s pre }}
$$

Keterangan:

$S$ post : Rata-rata skor Post-test

S pre : Rata-rata skor Pre-test

$S$ maks : Skor maksimal 
4599 Pengembangan Bahan Ajar untuk Meningkatkan Pemahaman pada Mata Kuliah Akuntansi MenengahElisabeth Margareta

DOI : https://doi.org/10.31004/edukatif.v3i6.1521

\section{HASIL DAN PEMBAHASAN PENELITIAN}

Produk yang dihasilkan dari penelitian dan pengembangan yang dilakukan oleh penulis merupakan bahan ajar interaktif mata kuliah Akuntansi Menengah, berupa e-modul pembelajaran yang menggabungkan teks, gambar, audio, animasi, dan video dalam satu file, yang kemudian linknya dibagikan kepada mahasiswa untuk digunakan pada kegiatan pembelajaran materi Kas dan Setara Kas. E-modul pembelajaran ini disusun menjadi satu file yang praktis sebab dapat dibaca dan didengar oleh mahasiswa tidak hanya dari perangkat komputer atau laptop tetapi bisa juga dari handphone sehingga mahasiswa dapat belajar dimana saja dan kapan saja.
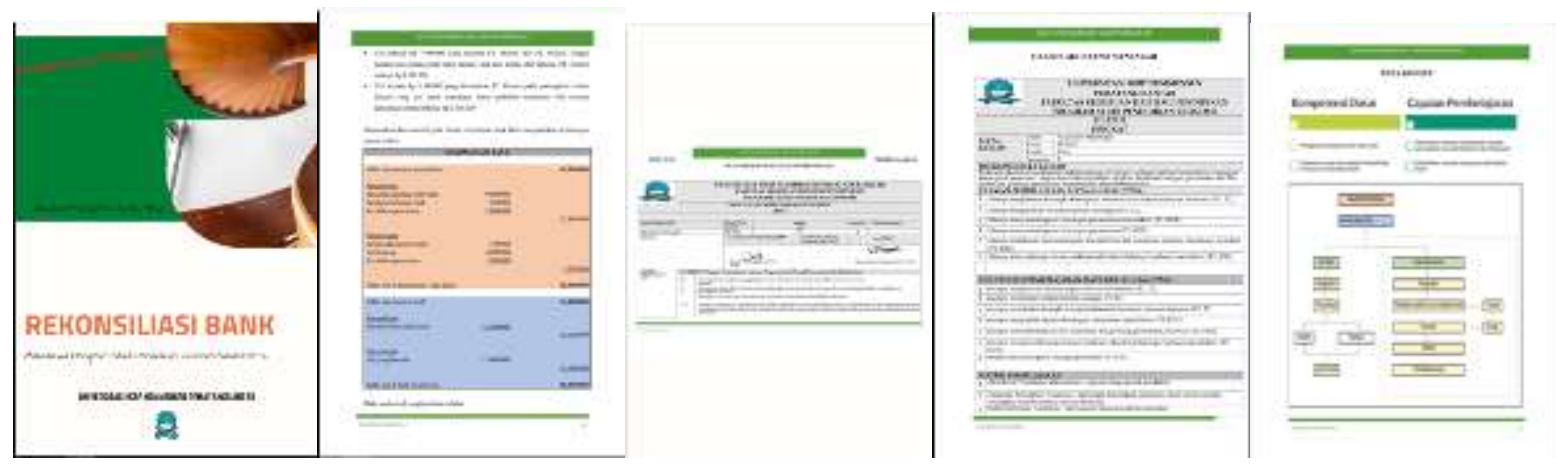

Gambar 1 : Tampilan Cover, Materi, RPS, Silabus, dan Peta Konsep E-Modul

Gambar di atas menyajikan tampilan bahan ajar interaktif yang dikembangkan, berupa cover e-modul, bagian dari materi, RPS, Silabus, dan peta konsep materi.
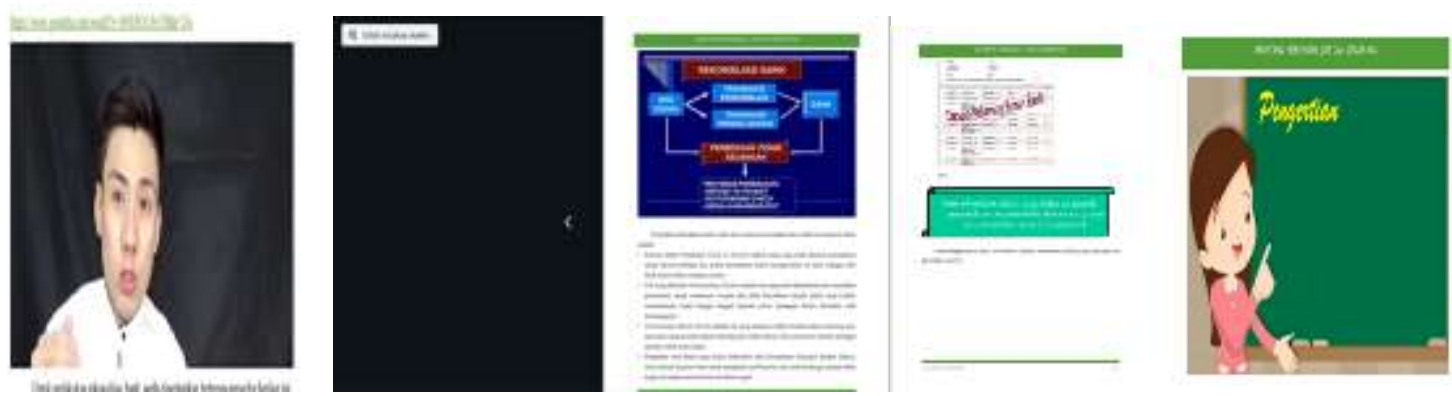

Gambar 2 : Tampilam Gambar, Audio, Animasi, dan Video E-Modul

Gambar di atas menunjukkan tampilan gambar, audio, animasi, dan video yang dimasukkan dalam emodul untuk menjelaskan materi.
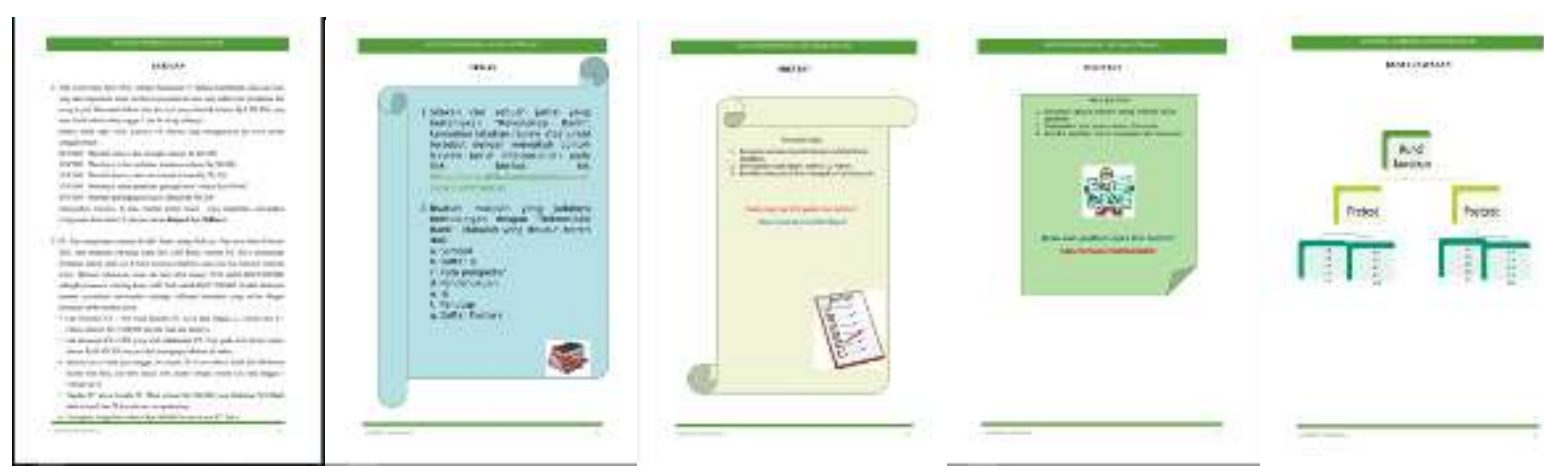

Gambar 3 : Tampilan Soal Latihan, Tugas, Pre-Test, Post-Test, dan Kunci Jawaban 
4600 Pengembangan Bahan Ajar untuk Meningkatkan Pemahaman pada Mata Kuliah Akuntansi MenengahElisabeth Margareta

DOI : https://doi.org/10.31004/edukatif.v3i6.1521

Gambar di atas menunjukkan tampilan soal-soal yang tersaji dalam e-modul, yang terdiri dari latihan, tugas, pre-test, post-test beserta kunci jawabannya.

Semua gambar di atas disajikan dalam satu file e-modul dengan menggunakan aplikasi desain yaitu canva. Selanjutnya link file e-modul inilah yang dibagikan kepada mahasiswa. Pada bagian akhir, penulis menambahkan petunjuk penggunaan e-modul seperti yang tersaji pada gambar di bawah ini, untuk memudahkan mahasiswa dalam menggunakan e-modul.

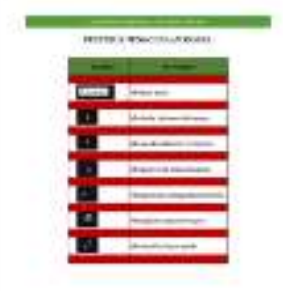

Gambar 4 : Petunjuk Penggunaan E-modul

Untuk menilai layak atau tidaknya produk (e-modul) yang dikembangkan oleh penulis maka dilakukan uji alpha dengan menggunakan instrumen yang telah divalidasi oleh ahli instrumen. Uji alpha dilakukan oleh 2 orang ahli materi, yang keduanya merupakan dosen program studi Pendidikan Ekonomi Fakultas Keguruan dan Ilmu Pendidikan (FKIP) Universitas HKBP Nommensen Pematangsiantar. Karena penelitian ini difokuskan pada efektivitas materi bahan ajar interaktif dalam meningkatkan pemahaman mahasiswa terhadap topik Rekonsiliasi Bank maka uji alpha hanya dilakukan oleh ahli materi saja.

Tabel 1. Validasi Aspek Pendahuluan, Isi, Latihan/ Tugas/ Uji Kompetensi oleh Ahli Materi

\begin{tabular}{|c|c|c|c|c|}
\hline \multirow{2}{*}{ Kriteria/ Aspek yang Dinilai } & \multicolumn{2}{|c|}{ Ahli Materi } & \multirow{2}{*}{ Total } & \multirow{2}{*}{ Rerata Skor } \\
\hline & $\mathrm{I}$ & II & & \\
\hline Pendahuluan & 3.67 & 3.67 & 7.33 & 3.67 \\
\hline Isi & 3.52 & 3.67 & 7.19 & 3.60 \\
\hline Latihan/ Tugas/ Uji Kompetensi & 3.50 & 3.33 & 6.83 & 3.42 \\
\hline \multicolumn{3}{|c|}{ Total Seluruhnya } & 21.36 & \\
\hline \multicolumn{3}{|c|}{ Rerata Skor Seluruhnya } & & 3.56 \\
\hline \multicolumn{3}{|c|}{ Kategori } & & Sangat Layak \\
\hline
\end{tabular}

Sumber: Data yang Diolah

Hasil validasi aspek pendahuluan, isi, latihan/ tugas/ uji kompetetnsi oleh ahli materi I dan II disajikan pada tabel 1 di atas, dimana diperoleh rerata skor seluruhnya sebesar 3,56. Jika $X \geq 3,0$ maka secara kualitatif termasuk dalam kategori sangat layak. Ini berarti hasil validasi ahli materi menunjukkan ketiga aspek sangat layak. Dengan demikian dapat artikan bahwa bahan ajar interaktif yang dikembangkan sangat layak untuk meningkatkan pemahaman pada mata kuliah Akuntansi Menengah sehingga layak untuk dilanjutkan ke uji beta dengan melakukan revisi sesuai saran ahli materi terlebih dahulu.

Tahap berikutnya dilakukan uji beta sebanyak dua kali. Uji beta 1 dilakukan pada kelompok kecil mahasiswa, yaitu 10 orang mahasiswa angkatan 2018 (grup A) di program studi Pendidikan Ekonomi, yang sudah pernah mempelajari materi Rekonsiliasi Bank. Berikut disajikan hasil uji beta 1 . 
4601 Pengembangan Bahan Ajar untuk Meningkatkan Pemahaman pada Mata Kuliah Akuntansi Menengah Elisabeth Margareta

DOI : https://doi.org/10.31004/edukatif.v3i6.1521

Tabel 2. Hasil Uji Beta 1 dari Ketiga Kriteria/ Aspek

\begin{tabular}{|c|c|}
\hline Kriteria/ Aspek & Rerara Skor \\
\hline Isi & 3.49 \\
\hline Tampilan & 3.68 \\
\hline Bahasa & 3.65 \\
\hline Total & 10.82 \\
\hline Rerata Skor Keseluruhan & 3.61 \\
\hline Kategori & Sangat Layak \\
\hline
\end{tabular}

Sumber: Data yang Diolah

Hasil uji beta 1 di atas menunjukkan bahwa keseluruhan aspek yang diujikan pada kelompok kecil mahasiswa menghasilkan rerata skor 3,61 ( $\mathrm{X} \geq 3,0)$. Ini menunjukkan bahwa bahan ajar interaktif yang dikembangkan (e-modul) sangat layak untuk diujikan pada kelompok besar mahasiswa (uji beta 2). Selanjutnya untuk uji beta 2, dilakukan uji coba kepada kelompok yang lebih besar, yaitu pada 53 orang mahasiswa angkatan 2019 (grup A) di program studi Pendidikan Ekonomi selaku subjek penelitian yang sedang mempelajari materi Rekonsiliasi Bank. Hasil uji beta 2 menunjukkan bahwa keseluruhan aspek pada bahan ajar interaktif yang dikembangkan (e-modul) sangat layak, yang ditunjukkan dari rerata skor ketiga aspek yaitu 3,63 $(X \geq 3,0)$. Berarti, seluruh aspek pada bahan ajar yang dikembangkan sangat layak untuk meningkatkan pemahaman materi Rekonsiliasi Bank. Berikut disajikan hasil uji beta 2.

Tabel 3. Hasil Uji Beta 2 dari Ketiga Kriteria/ Aspek

\begin{tabular}{|c|c|}
\hline Kriteria/ Aspek & Rerara Skor \\
\hline Isi & 3.53 \\
\hline Tampilan & 3.57 \\
\hline Bahasa & 3.78 \\
\hline Total & 10.88 \\
\hline Rerata Skor Keseluruhan & 3.63 \\
\hline Kategori & Sangat Layak \\
\hline
\end{tabular}

Sumber: Data yang Diolahs

Untuk mengetahui bagaimana efektivitas pengembangan bahan ajar dalam meningkatkan pemahaman materi Rekonsiliasi Bank pada mata kuliah Akuntansi Menengah, kepada 53 orang mahasiswa angkatan 2019 (grup A) di program studi Pendidikan Ekonomi diberikan soal pre-test dan post-test. Skor pre-test dan posttest mahasiswa menunjukkan terjadi peningkatan rata-rata skor mahasiswa setelah menggunakan bahan ajar interaktif, dari 33,49 meningkat menjadi 81,13. Selanjutnya dilakukan perhitungan dengan menggunakan rumus rata-rata gain yang dibandingkan ( $\mathrm{N}$-gain), diperoleh skor gain sebesar 0,72 yang menunjukkan bahwa perbandingan skor rata-rata mahasiswa sebelum dengan sesudah menggunakan bahan ajar interaktif masuk dalam kategori tinggi ( $\mathrm{N}$-Gain $\geq 0,7$ ), artinya penggunaan bahan ajar interaktif dalam proses pembelajaran mata kuliah Akuntansi Menengah sangat efektif dalam meningkatkan pemahaman materi Rekonsiliasi Bank. Hasil pre-test dan post-test juga menunjukkan terjadi peningkatan skor pada masing-masing butir soal setelah menggunakan bahan ajar interaktif, artinya terjadi peningkatan kemampuan mahasiswa dalam memahami setiap butir soal sehingga dapat disimpulkan bahwa bahan ajar interaktif yang dikembangkan efektif meningkatkan pemahaman mahasiswa pada materi Rekonsiliasi Bank mata kuliah Akuntansi Menengah. Hal ini sejalan dengan penelitian (Nurhairunnisah \& Sujarwo, 2018) yang menyatakan bahwa peningkatan terhadap nilai rata-rata posttest menunjukkan bahwa secara umum bahan ajar interaktif efektif meningkatkan 
4602 Pengembangan Bahan Ajar untuk Meningkatkan Pemahaman pada Mata Kuliah Akuntansi MenengahElisabeth Margareta

DOI

pemahaman konsep matematika setelah siswa menggunakan produk dalam pembelajaran. Selain itu sejalan juga dengan hasil penelitian (Wulansari et al., 2018), yang menunjukkan bahwa "berdasarkan hasil belajar siswa pada kelas uji coba kelompok terbatas dan uji coba kelompok luas terdapat perbedaan hasil uji pretest dan postest. Dengan melihat perbedaan hasil belajar siswa tersebut diketahui bahwa dengan menggunakan $e$ modul pembelajaran ekonomi menjadikan siswa mudah paham terhadap materi yang dipelajari yaitu materi pasar modal". Penelitian (Siti Nurjannah Iswandari, Jimmi Copriady*, Asmadi M Noer, 2020) juga menunjukkan hal yang sama, bahwa hasil uji respon terhadap penggunaan e-modul berbasis Moodle dari peserta didik memperoleh skor $91,67 \%$ dan guru $93,45 \%$, artinya e-modul yang telah dikembangkan dapat menjadi salah satu sumber belajar/ bahan ajar yang dapat digunakan saat pembelajaran. Berikut ini disajikan peningkatan skor pada masing-masing butir soal setelah menggunakan bahan ajar interaktif materi Rekonsiliasi Bank.

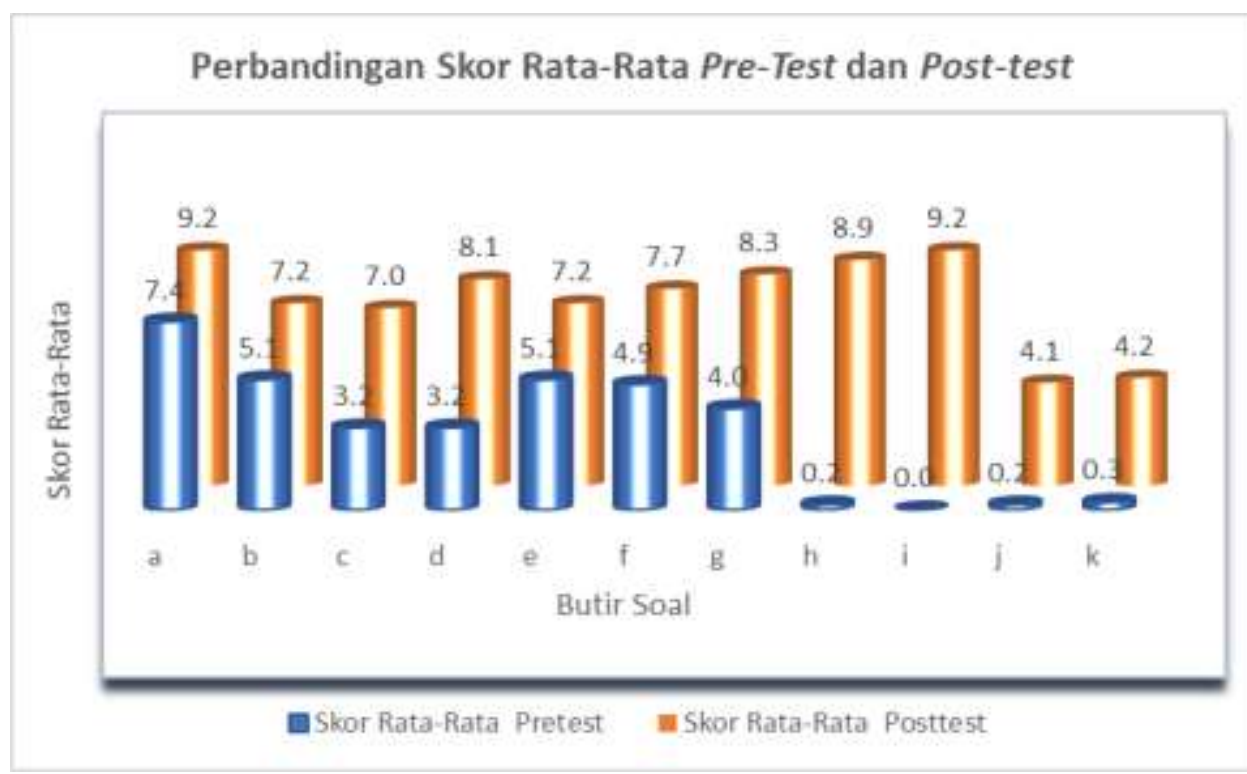

Gambar 5 : Perbandingan Skor Rata-Rata Pre-Test dan Post-Test

\section{KESIMPULAN}

Berdasarkan hasil penelitian dan pengembangan yang dilakukan diperoleh kesimpulan bahwa prosedur pengembangan bahan ajar interaktif dilakukan dengan merencanakan konsep bahan ajar interaktif, kemudian membuat desain bahan ajar, lalu melakukan pengembangan sesuai kebutuhan. Berikutnya, untuk menilai layak atau tidaknya produk yang dikembangkan (e-modul) dilakukan uji alpha, hasilnya bahan ajar interaktif yang dikembangkan sangat layak digunakan pada pembelajaran Akuntansi Menengah. Selanjutnya dilakukan uji beta. Uji beta 1 dilakukan pada kelompok kecil mahasiswa, hasilnya bahan ajar interaktif yang dikembangkan sangat layak sehingga dapat dilanjutkan dengan uji beta 2. Uji beta 2 dilakukan pada kelompok besar mahasiswa, dengan hasil bahan ajar interaktif yang dikembangkan sangat layak digunakan pada mata kuliah Akuntansi Menengah materi Rekonsiliasi Bank. Untuk mengetahui bagaimana efektivitas pengembangan bahan ajar dalam meningkatkan pemahaman materi Rekonsiliasi Bank pada mata kuliah Akuntansi Menengah, langkah terakhir yang dilakukan adalah memberikan soal pre-test dan post-test. Hasilnya, penggunaan bahan ajar interaktif sangat efektif dalam meningkatkan pemahaman materi Rekonsiliasi Bank, yang terlihat dari skor rata-rata pre-test dan post-test mahasiswa, dimana terjadi peningkatan setelah menggunakan bahan ajar interaktif dan ketika dilakukan perhitungan dengan menggunakan rumus rata-rata gain yang dibandingkan ( $\mathrm{N}$-gain) diperoleh hasil bahwa penggunaan bahan ajar 
4603 Pengembangan Bahan Ajar untuk Meningkatkan Pemahaman pada Mata Kuliah Akuntansi MenengahElisabeth Margareta

DOI : https://doi.org/10.31004/edukatif.v3i6.1521

interaktif mampu meningkatkan pemahaman mahasiswa pada materi Rekonsiliasi Bank dengan kategori tinggi.

\section{DAFTAR PUSTAKA}

Anwar. (2010). Pengembangan Bahan Ajar : Bahan Kuliah Online. Direktori Upi.

Hake. (1998). Interaktive-Engagement Vs Traditional Methods: A Six-Thousandstudent Survey Of Mechanicstest Data For Introductory Physics Course. The American Journal Of Physics Research, 66, 64-74.

Husada, S. P. (2020). Pengembangan Bahan Ajar Pembelajaran Tematik Dengan Menggunakan Metode Visual Storytelling Di Sekolah Dasar. Basicedu, 4, 419-425.

Irawati, E., \& Susetyo, W. (2017). Implementasi Undang-Undang Nomor 20 Tahun 2003 Tentang Sistem Pendidikan Nasional Di Blitar. Jurnal Supremasi, 3.

Margareta, E. (2020). Pengaruh Model Pembelajaran Aktif Group To Group Exchange Terhadap Hasil Belajar Akuntansi Lanjutan Di Program Studi Pendidikan Ekonomi Universitas Hkbp Nommensen Pematangsiantar. Jurnal Ilmiah Simantek, 4(3), 139-147.

Meidy, R. D., Patmanthara, S., \& Arifin, M. Z. (2018). Pengembangan Bahan Ajar Cetak Dengan Model Discovery Learning Untuk Mata Pelajaran Komputer Dan Jaringan Dasar Kelas X. Jurnal Pendidikan (Teori Dan Praktik), 3(2), 126. Https://Doi.Org/10.26740/Jp.V3n2.P126-133

Nurhairunnisah, N., \& Sujarwo, S. (2018). Bahan Ajar Interaktif Untuk Meningkatkan Pemahaman Konsep Matematika Pada Siswa Sma Kelas X. Jurnal Inovasi Teknologi Pendidikan, 5(2), 192-203. Https://Doi.Org/10.21831/Jitp.V5i2.15320

Prastowo. (2012). Panduan Kreatif Membuat Bahan Ajar Inovatif. Diva Press.

Purmadi, A., \& Surjono, H. D. (2016). Pengembangan Bahan Ajar Berbasis Web Berdasarkan Gaya Belajar Siswa Untuk Mata Pelajaran Fisika. Jurnal Inovasi Teknologi Pendidikan, 3(2), 151. Https://Doi.Org/10.21831/Jitp.V3i2.8285

Purnamasari, P., Annur, S., \& M., A. S. (2016). Pengembangan Bahan Ajar Melalui Model Pembelajaran React Pada Materi Elastisitas. Berkala Ilmiah Pendidikan Fisika, 4(3), 209. Https://Doi.Org/10.20527/Bipf.V4i3.1006

Rudianto. (2012). Pengantar Akuntansi. Erlangga.

Selvia, M., Arifuddin, M., \& Mahardika, A. I. (2017). Pengembangan Bahan Ajar Fisika Sma Topik Fluida Berorientasi Masalah Lahan Basah Melalui Pendekatan Contextual Teaching And Learning (Ctl). Berkala Ilmiah Pendidikan Fisika, 5(2), 213. Https://Doi.Org/10.20527/Bipf.V5i2.2896

Seso, M. A., Laksana, D. N. L., \& Dua, K. (2019). Pengembangan Bahan Ajar Elektronik Bermuatan Multimedia Untuk Siswa Sekolah Dasar Kelas Iv Di Kabupaten Ngada. Journal Of Education Technology, 2(4), 177. Https://Doi.Org/10.23887/Jet.V2i4.16546

Setyo, F., \& Pribowo, P. (2017). Pengembangan Bahan Ajar Mata Kuliah Ipa Berbasis Scientific Aprroach Merupakan Perpaduan Proses Pembelajaran Yang Semula Terfokus Pada Eksplorasi, Elaborasi , Dan Konfirmasi Dilengkapi Dengan Mengamati , Mengkomunikasikan ( Kemendikbud, 2013 ). Scientif. 3833, 54-66.

Setyosari. (2013). Metode Penelitian Pendidikan \& Pengembangan. Kencana.

Siahaan, K. W. A., Lumbangaol, S. T. P., Marbun, J., Nainggolan, A. D., Ritonga, J. M., \& Barus, D. P. (2021). Pengaruh Model Pembelajaran Inkuiri Terbimbing Dengan Multi Representasi Terhadap Keterampilan Proses Sains Dan Penguasaan Konsep Ipa. Jurnal Basicedu, 5(1), 195-205.

Siti Nurjannah Iswandari, Jimmi Copriady*, Asmadi M Noer, S. W. A. (2020). Pengembangan E-Modul 
4604 Pengembangan Bahan Ajar untuk Meningkatkan Pemahaman pada Mata Kuliah Akuntansi MenengahElisabeth Margareta

DOI : https://doi.org/10.31004/edukatif.v3i6.1521

Berbasis Moodle Pada Materi Hidrokarbon Development Of E-Modul Based On Moodle In Hydrocarbon Topic. Edusains, 12(1), 81-88.

Sulasteri, S., Ainun, A. M., Rasyid, M. R., Matematika, P., \& Alauddin, U. I. N. (2021). Edukatif: Jurnal Ilmu Pendidikan Pengembangan Bahan Ajar Berbantuan Software Maple Pada Mata Kuliah Kalkulus I. 3(6), 3898-3904.

Sulistyowati, P., \& Putri, N. M. (2018). Pengembangan Bahan Ajar Modul Berbasis Contextual Teaching And Learning (Ctl) Kelas Iv Tema 3 Subtema 1. Jurnal Pendidikan (Teori Dan Praktik), 3(1), 1. Https://Doi.Org/10.26740/Jp.V3n1.P1-6

Susanto, H., \& Akmal, H. (2019). Media Pembelajaran Sejarah Era Teknologi Informasi (Konsep Dasar, Prinsi Aplikatif, Dan Perancangannya). Fkip Universitas Lambung Mangkurat.

Tania, L. (2017). Pengembangan Bahan Ajar E-Modul Sebagai Pendukung Pembelajaran Kurikulum 2013 Pada Materi Ayat Jurnal Penyesuaian Perusahaan Jasa Siswa Kelas X Akuntansi Smk Negeri 1 Surabaya. Jurnal Pendidikan Akuntansi (Jpak), 5(2), 1-9.

Warkintin, W., \& Mulyadi, Y. B. (2019). Pengembangan Bahan Ajar Berbasis Cd Interaktif Power Point Untuk Meningkatkan Hasil Belajar Siswa. Scholaria: Jurnal Pendidikan Dan Kebudayaan, 9(1), 82-92. Https://Doi.Org/10.24246/J.Js.2019.V9.I1.P82-92

Widiana, F. H., \& Rosy, B. (2021). Edukatif: Jurnal Ilmu Pendidikan Pengembangan E-Modul Berbasis Flipbook Maker Pada Mata Pelajaran Teknologi Perkantoran. 3(6), 3728-3739.

Wulansari, E. W., Kantun, S., \& Suharso, P. (2018). Pengembangan E-Modul Pembelajaran Ekonomi Materi Pasar Modal Untuk Siswa Kelas Xi Ips Man 1 Jember Tahun Ajaran 2016/2017. Jurnal Pendidikan Ekonomi: Jurnal Ilmiah Ilmu Pendidikan, Ilmu Ekonomi Dan Ilmu Sosial, 12(1), 1. Https://Doi.Org/10.19184/Jpe.V12i1.6463

Yaumi. (2018). Media Dan Teknologi Pembelajaran. Kencana. 